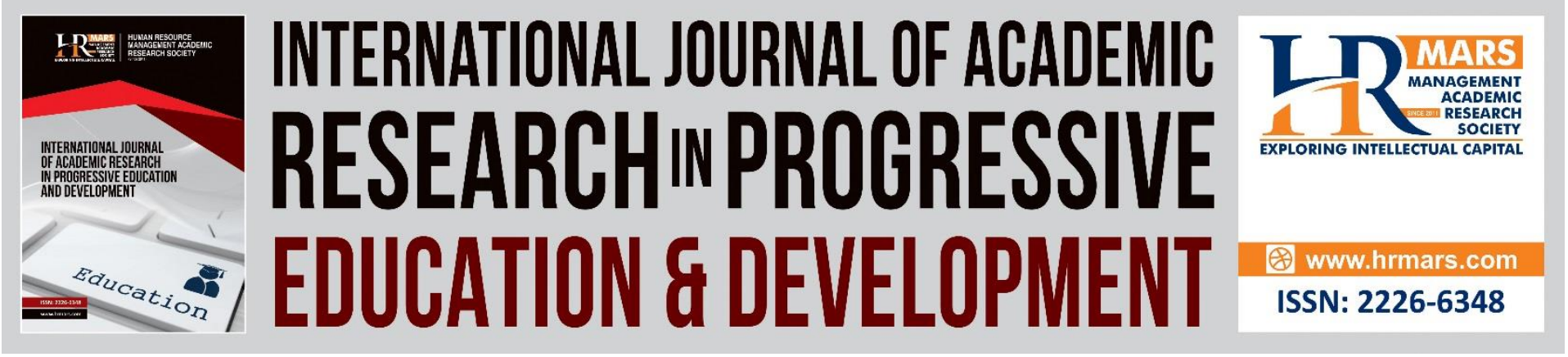

\title{
Psychological Development of Parents Towards the Home- Based Teaching and Learning (PdPR) Process During the Movement Control Order (MCO): Causes and Issues
}

Hamidah Jalani, Nor Adina Abdul Kadir, Mariam Farhana Md Nasir, Izzah Nur Aida Zur Raffar, Sarah Dina Mohd Adnan, Nang Naemah Nik Dahalan

To Link this Article: http://dx.doi.org/10.6007/IJARPED/v10-i3/11634 DOI:10.6007/IJARPED/v10-i3/11634

Received: 26 July 2021, Revised: 29 August 2021, Accepted: 12 September 2021

Published Online: 28 September 2021

In-Text Citation: (Jalani et al., 2021)

To Cite this Article: Jalani, H., Kadir, N. A. A., Nasir, M. F. M., Raffar, I. N. A. Zur, Adnan, S. D. M., \& Dahalan, N. N. N. (2021). Psychological Development of Parents Towards the Home-Based Teaching and Learning (PdPR) Process During the Movement Control Order (MCO): Causes and Issues. International Journal of Academic Research in Progressive Education and Development, 10(3), 1229-1240.

Copyright: (c) 2021 The Author(s)

Published by Human Resource Management Academic Research Society (www.hrmars.com)

This article is published under the Creative Commons Attribution (CC BY 4.0) license. Anyone may reproduce, distribute, translate and create derivative works of this article (for both commercial and non-commercial purposes), subject to full attribution to the original publication and authors. The full terms of this license may be seen at: http://creativecommons.org/licences/by/4.0/legalcode

Vol. 10(3) 2021, Pg. 1229 - 1240

http://hrmars.com/index.php/pages/detail/IJARPED

JOURNAL HOMEPAGE

Full Terms \& Conditions of access and use can be found at http://hrmars.com/index.php/pages/detail/publication-ethics 


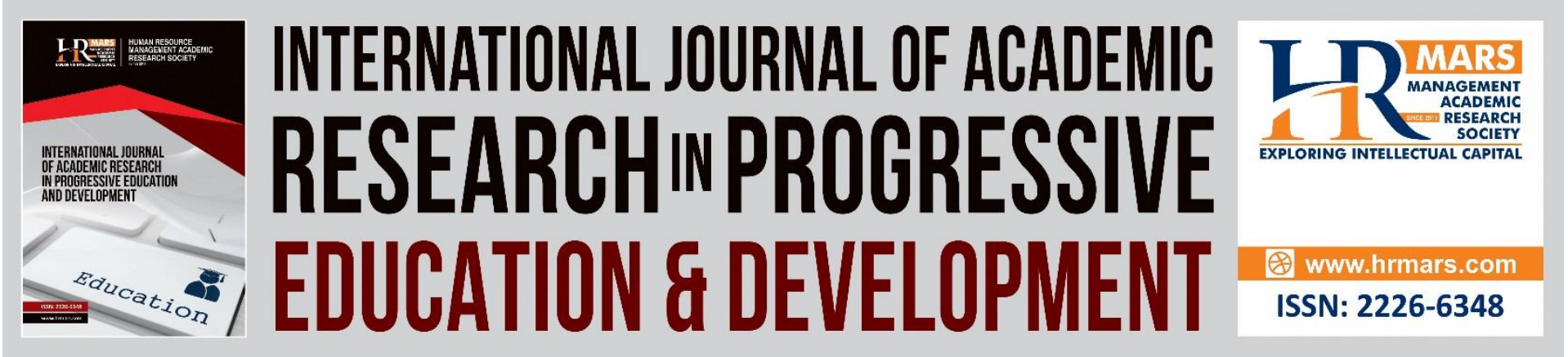

\title{
Psychological Development of Parents Towards the Home-Based Teaching and Learning (PdPR) Process During the Movement Control Order (MCO): Causes and Issues
}

\author{
Hamidah Jalani, Nor Adina Abdul Kadir, Mariam Farhana Md \\ Nasir, Dr. Izzah Nur Aida Zur Raffar, Sarah Dina Mohd Adnan, \\ Nang Naemah Nik Dahalan \\ Lecturer at Academy of Contemporary Islamic Studies (ACIS), UiTM Melaka Branch. KM 26, \\ Jalan Lendu, 78000 Alor Gajah, Melaka \\ Email: noradina@uitm.edu.my, hamidahjalani@uitm.edu.my, \\ mariamfarhana@uitm.edu.my, izzahnur@uitm.edu.my, sarahdina@uitm.edu.my, \\ nangnaemah@uitm.edu.my
}

\begin{abstract}
The Movement Control Order (MCO) implemented saw reforms in the field of education. Students have to undergo Home-Based Teaching and Learning (PdPR) as recommended by the Ministry of Education Malaysia. However, the PdPR method requires parents to monitor their children's PdPR activities at home. This leads to an increase in psychological problems, especially among parents. According to the Islamic perspective, methods of overcoming the psychological stress of parents during the MCO period are urgent that should be given attention to enable children and families to thrive in online learning. Furthermore, this study was conducted to analyze and identify the causes of parental psychological stress on the PdPR process. The design of this research uses a survey through the use of a questionnaire conducted on 516 respondents who were selected deliberately (purposive sampling) among Muslim parents in Malaysia. In addition, data were analyzed by descriptive statistical methods using SPSS. The results showed several reasons identified such as lack of electronic devices for PdPR, inefficient time management, and external pressure from teachers exacerbated the psychological development of parents. The results of the study can also be used to assist relevant agencies in relieving parental psychological stress during MCO.
\end{abstract}

Keywords: Psychology, Causes, Parents, PdPR, MCO

Introduction

The Movement Control Order 1.0 (MCO 1.0), Conditional Movement Control Order (CMCO), and Movement Control Order 3.0 (MCO 3.0) are preventative measures taken by the government to combat the spread of COVID-19. Several guidelines were issued through the implementation of $\mathrm{MCO}$ and $\mathrm{CMCO}$ to restrict the movement of individuals within the 
community. Economic sectors and activities that were deemed non-essential halted operations to reduce the risk of transmission among the population. The education sector was also impacted by the aforementioned guideline. As a result, children were not allowed to attend school. Instead, their learning sessions were conducted online in what is known as the Home-Based Teaching and Learning (PdPR) method. The method requires teachers to conduct their classes online through mobile or desktop applications on their devices.

This situation may appear fun and enjoyable as teachers and students are not required to attend schools physically, and all activities are conducted with the use of gadgets such as computers, laptops, tablets, or mobile phones. Once a learning session has been completed, students will be given exercises to complete within a designated timeframe by their teachers. Learning and teaching with the PdPR method at the beginning stage was lax and enjoyable. Although with time, teachers and students grew tired of PdPR. Teachers were at their wits end in finding effective teaching techniques whereas students were burned out from excessive screen time and online learning.

This is an issue that not only involves teachers and students, but also the parents who act as 'stand-in teachers' for their children. Based on observation, it is found that parents often become the 'student' while simultaneously taking up the role of the 'teacher' for their children. Older children may not face difficulties in focusing or revising for their classes, but younger children require parental supervision and guidance in attending virtual classes and completing their assigned works. Therefore, parents play a crucial role in ensuring the success of the PdPR method. Children whose parents are frontliners have to be sent to daycare centres. On the other hand, parents who work-from-home (WFH) have to manage their affairs with numerous constraints including carrying out their own workload, supervising their children, and dealing with housework. They also have to deal with interferences from their prospective partners. These factors contribute to stress. The stress in question is in the form of an emotional disorder, which can be classified as a psychological problem. Thus, this project paper will address and classify the causes of psychological stress among parents due to PdPR during the MCO period.

\section{Literature Review}

Pandemic-related research has been done increasingly as of late as the world continues to deal with the COVID-19 pandemic. Research regarding the pandemic includes those by Talha, 2020). Greyling et al (2020); Brooks et al (2020); Jiao et al (2020); Orgiles et al (2020); Sahid, et al (2020); Li et al (2020). The COVID-19 pandemic has changed the everyday lives of people. Social restrictions enforced by most countries including Malaysia impacted the country's political, economic, social, health and education systems (Rashid, et al., 2020). Preventative measures like the Movement Control Order that restricts a considerable number of social activities has led to an abrupt change in lifestyle for the people (Talha, 2020).

In terms of public health and safety, these measures have been proven to be beneficial for the community. Nevertheless, it cannot be denied that the imposed restrictions have had adverse effects on individuals, families, and society. From an economic standpoint, Western and local researchers have agreed (Rashid, et al., 2020) that labour markets worldwide would be impacted due to the side effects in demand and supply. This has resulted in the disruption of economic activities that affect the income of households and businesses in rural areas (Philipson et al., 2020). 
The consequences of these side effects have indirectly triggered detrimental implications on all aspects of life, notably emotional effects on individuals, which in turn can cause deterioration in familial institutions. Studies conducted by Brooks et al (2020) Jiao et al (2020); Orgiles et al (2020) have revealed how social restrictions affect the emotional wellbeing of adults and children. This is due to the fact that limitations and restrictions placed on most if not all social activities are new and unusual, thus contributing to the increase in domestic conflict. These adverse repercussions are also being experienced by those living in Malaysia, where the pandemic has inflicted negative psychological effects on individuals (Ali \& Rashid, 2020). such as increased levels of anxiety, loneliness and depression as a result of lengthy lockdown periods and persisting economic pressure.

The impact of the pandemic extends to familial institutions globally. In France, stress as a result of financial issues has led to an increase in domestic violence of approximately 32 per cent within the one week of compulsory lockdown in the country (Mapjabil et al., 2020). The same can be said in China where the drastic increase of domestic violence prompted an upwards trend in divorce cases of as much as 25 per cent in mid-March 2020 in the Xian and Dazhou prefectures (Mapjabil et al., 2020). Therefore, the reoccurring stress stems from the financial crisis, which consequently leads to domestic misconduct inclusive of domestic violence, runaway, and suicide cases.

Truthfully, whilst the implementation of MCO contributed to the overall decrease of COVID-19 cases, it had also contributed to the instability of familial institutions (Hamjah, 2020). Majid (2020) highlighted that the abrupt change in routine experienced by members of a household is a major contributing factor to the emotional instability of each individual, resulting in dissimilar and conflicting reactions within a household. Examples of changes in routine are managing the household, working, and social routines. When a family manager (the member of the family who is in charge of managing the household) is unprepared physically and mentally to deal with any sort of situation in this challenging period, it can become a cause of familial dysfunction; which could eventually lead to divorce. It is also found that parents were concerned about their children's emotional and mental health during the MCO (Hayin, 2020). seeing that children were also stressed and burdened by PdPR (Megat, 2021).

A study conducted by UNICEF Malaysia (2020) on residents of 500 low-cost housing units in Kuala Lumpur reported alarming findings of which more than 40 per cent of respondents experienced emotional distress. The respondents' state of emotional distress was classified as due to being "afraid of their family's future" (UNICEF, 2021). The findings are an indication that the emotional distress experienced by the head of the household towards their family's future stems from the seemingly endless COVID-19 pandemic. Henceforth, this current situation calls for self-adjustment and proper coping strategies (Sahid, et al., 2020) to strengthen familial institutions as a way to move forward and adhere to new norms and postpandemic life.

In addition, a cramped or overcrowded living environment causes limited movements, thus causing stress upon members of the family (Harian, 2020). Hence, it is crucial for parents and other members of the household to remain positive and rational to maintain their emotional wellbeing and prevent any negative psychological impacts. Whilst negative emotions are experienced by most people during $\mathrm{MCO}$, it should be noted that those living in cramped and crowded living spaces such as flats and apartments experience it to a higher degree. A physically restrictive home environment, as well as ongoing financial troubles 
DEVELOPMENT

Vol. 10, No. 3, 2021, E-ISSN: 2226-6348 @ 2021 HRMARS

during MCO (Chabraa, 2020), are factors that induce high levels of stress in parents, which would eventually affect their own families. Psychological impacts that parents or families may face include being in a constant state of anxiety, inability to focus on tasks, irritability, negative thinking patterns, and suicidal thoughts.

\section{Problem Statement}

\begin{tabular}{|c|c|c|}
\hline Author + Year & Cause & Explanation \\
\hline 1. $\operatorname{Lim}(2020)$ & $\begin{array}{l}\text { Emotional disturbance within } \\
\text { children }\end{array}$ & $\begin{array}{l}\text { Parents are faced with the challenge of } \\
\text { ensuring that their children are not under any } \\
\text { emotional disturbance or behavioural disorder. } \\
\text { Lim (2020) asserts that an organised daily } \\
\text { routine helps build healthy behaviour and } \\
\text { reduces stress. Besides that, parents can } \\
\text { manage their children's activities or organise a } \\
\text { daily schedule to lessen their children's worries } \\
\text { and overcome their boredom. In this situation, } \\
\text { parents should communicate with their } \\
\text { children more frequently to allow for the young } \\
\text { ones to discuss their feelings and tamp down } \\
\text { any concerns and worries. It is also } \\
\text { recommended for parents to monitor and limit } \\
\text { their children's social media usage if they } \\
\text { appear to be overexposed to sensitive issues or } \\
\text { obtain inaccurate information that invokes } \\
\text { anxiety and depression. }\end{array}$ \\
\hline $\begin{array}{l}\text { 2. Choi et al., } \\
(2020)\end{array}$ & $\begin{array}{l}\text { Worrying excessively about } \\
\text { COVID-19 }\end{array}$ & $\begin{array}{l}\text { The COVID-19 outbreak and the extension of } \\
\text { the Movement Control Order (MCO) are factors } \\
\text { that could impact an individual's emotions, } \\
\text { thoughts and behaviour. Parents are not } \\
\text { exempt from the psychosocial effects of the } \\
\text { pandemic. Some parents have revealed that } \\
\text { they excessively worry about the spread of } \\
\text { COVID-19 compared to their own personal and } \\
\text { familial problems. As a result, their excessive } \\
\text { worrying might cause secondhand anxiety for } \\
\text { their children. Secondhand anxiety is the } \\
\text { phenomenon of stress spreading; hence, } \\
\text { children might also worry excessively about the } \\
\text { pandemic because of their parents. The } \\
\text { uncertainty surrounding the current situation } \\
\text { invokes feelings and thoughts of anxiety and } \\
\text { worry; this is a normal reaction to the situation. } \\
\text { However, it is advised for parents to not appear } \\
\text { excessively worried in front of their children to } \\
\text { avoid them from worrying as well. Parents } \\
\text { should uplift themselves with prayers and zikr } \\
\text { for their troubles to be eased with the hopes }\end{array}$ \\
\hline
\end{tabular}




\begin{tabular}{|c|c|c|}
\hline & & $\begin{array}{l}\text { that Allah will bestow upon them strength to } \\
\text { endure these challenging times. Parents should } \\
\text { also look at things from a positive perspective. } \\
\text { The MCO period should be seen as an } \\
\text { opportunity for parents to become even more } \\
\text { productive, strengthen and improve their } \\
\text { relationship with their children, and carry out } \\
\text { enjoyable hobbies and activities. }\end{array}$ \\
\hline $\begin{array}{l}\text { 3. Berita Harian } \\
(2020)\end{array}$ & Cramped living space & $\begin{array}{l}\text { It is of utmost importance for family members } \\
\text { to remain rational and positive during MCO to } \\
\text { avoid negative psychological impacts. It is } \\
\text { undeniable that most parents will experience } \\
\text { varying degrees of stress and anxiety as a result } \\
\text { of the MCO. However, the effects are much } \\
\text { more pronounced among those living in } \\
\text { cramped and crowded houses such as flats or } \\
\text { apartments. Small and overcrowded living } \\
\text { spaces, when combined with financial issues } \\
\text { are enough to cause parents to be } \\
\text { overwhelmed. In turn, this will affect the } \\
\text { harmony and wellbeing of the family. } \\
\text { Psychological impacts that may be experienced } \\
\text { by family members include being in a constant } \\
\text { state of anxiety, inability to focus on tasks, } \\
\text { irritability, negative thing, and suicidal ideation. }\end{array}$ \\
\hline 4. Chabraa (2020) & Economic impact & $\begin{array}{l}\text { Financial issues and poverty are major stressors } \\
\text { in a person's life. Global experts have warned } \\
\text { that the impact of COVID-19 on the economy } \\
\text { and businesses, as well as unemployment could } \\
\text { damage a person's self-esteem, which could } \\
\text { ultimately lead to suicidal thoughts. The } \\
\text { economic fallout from COVID-19 has prompted } \\
\text { many to be laid off from their jobs. Choi et al. } \\
\text { (2020) has stated that there are also workers } \\
\text { who experience a salary cut because of the } \\
\text { pandemic. This is a major cause of concern for } \\
\text { certain communities as their careers and } \\
\text { futures are on the line. Breadwinners feel } \\
\text { especially burdened by these changes as they } \\
\text { feel pressured to support the rest of their } \\
\text { families. }\end{array}$ \\
\hline $\begin{array}{l}\text { 5. Mustaffa } \\
(2020)\end{array}$ & School closure & $\begin{array}{l}\text { From an educational standpoint, schools are } \\
\text { forced to close during MCO. Teachers make do } \\
\text { with available facilities to provide online } \\
\text { learning sessions for their students. The main } \\
\text { hindrance with online classes is internet } \\
\text { connectivity and the lack of gadgets. These } \\
\text { issues are especially common for those living in } \\
\text { rural areas. Certain families are unable to afford } \\
\text { gadgets for online learning, thus causing } \\
\text { parents to feel burdened. }\end{array}$ \\
\hline $\begin{array}{l}\text { 6. Irawan et al., } \\
(2020)\end{array}$ & Workload from online learning & $\begin{array}{l}\text { Online assignments are a stressor for students, } \\
\text { where they are required to immediately master } \\
\text { a recently learned topic and complete their } \\
\text { assigned online work. Aside from that, the }\end{array}$ \\
\hline
\end{tabular}




\begin{tabular}{|c|c|c|}
\hline & & $\begin{array}{l}\text { enforced lockdown has caused students to be } \\
\text { confined within their homes with a lack of } \\
\text { physical interaction with peers, and reduced } \\
\text { physical activities. These factors bring about } \\
\text { negative psychological impacts among } \\
\text { students. In retrospect, worried and anxious } \\
\text { students cause their parents to worry for them } \\
\text { as well }\end{array}$ \\
\hline 7. Jarnawi, (2020) & $\begin{array}{l}\text { Supervising children's learning } \\
\text { sessions and becoming the } \\
\text { 'teacher' }\end{array}$ & $\begin{array}{l}\text { Teachers and students are unable to attend } \\
\text { schools physically by virtue of restricting social } \\
\text { interactions to reduce COVID-19 transmission. } \\
\text { Thereupon students are not able to study or } \\
\text { learn properly because of inadequate study } \\
\text { sources and limited internet connection. } \\
\text { Parents are then burdened with the task of } \\
\text { having to take over the role of a teacher and } \\
\text { thoroughly supervise their children's at-home } \\
\text { learning to fully ensure that they understand } \\
\text { the topics they have learned. }\end{array}$ \\
\hline
\end{tabular}

\section{Methodology}

The research design of the project utilises surveying through the use of a questionnaire that was carried out on 516 respondents who were purposely chosen (purposive sampling) among Muslim parents in Malaysia. The main instrument used in this research for data collection is a questionnaire that was distributed through the platform, Google Form. The reliability of the instrument was obtained through a pilot study to test the internal consistency of the questionnaire with the Cronbach's Alpha index. Researchers conducted the pilot study on 50 parents consisting of Universiti Teknologi Mara Cawangan Melaka staff. Results of the pilot study were then analysed using the Cronbach's Alpha (a) reliability test which eventually showed the value of the reliability coefficient of 0.851 .

Therefore, the reliability value of the questionnaire instrument in this study indicates that the instrument is in a position of high reliability, efficacy and consistency. Thus, the questionnaire can be used for actual research (Sekaran, 2003). Choice of answers was measured with the Likert scale where a score of ' 1 ' indicated Strongly Disagree, ' 2 ' indicated Disagree, ' 3 ' indicated Agree and ' 4 ' indicated Strongly Agree. Next, the data from the questionnaire were analysed using the software programme Statistical Package for The Social Sciences (SPSS). The analysis process involves the descriptive statistic method which was presented as frequency (F), percentage (\%), and the mean value to discuss the research results. The use of such methods is appropriate in answering the study's targeted objectives and problem statement.

\section{Results and Discussion}

The online method of Home-Based Teaching and Learning (PdPR) has become a need for students and teachers in Malaysia especially in facing the COVID-19 pandemic. This method has affected a lot of people especially parents. This is due to parents having to take over the role of teachers to teach their children at home. Thus, this situation will give some impact on children's learning. Since March 2020, it was informed by the Malaysian Ministry of Education (MOE) regarding the execution of PdPR. According to MOE, PdPR is a homebased teaching and learning method that can be carried out at home, a community centre, or 
any suitable place. PdPR can be carried out online, offline, or in more structured and organised places such as the park or the library. There are some causes of psychological stress among parents throughout PdPR sessions with children at home.

\section{i) Lack of Gadgets for PdPR Session}

The PdPR method has affected many communities in Malaysia, especially parents. Most parents in Malaysia come from the lower-income class, B40. As shown on television, most of them were heavily affected in terms of the economy because of the pandemic that has caused unemployment, decreasing sales in business and many more. This situation has caused parents of B40 households to face problems in providing suitable devices such as mobile phones and laptops which are essential for PdPR. Apart from that, parents of B40 households from rural areas face issues in providing sufficient internet data and mobile phone credit along with issues on internet connection speed.

Buang \& Lee (2020) reported in malaysiakini.com that a 42-year-old housewife named Jumiati llyas, bewail the fate of her family since the start of PdPR. She is a mother that has always focused on her children's needs and monetary savings. Now, she has to work twice as hard to afford the needs of her family and her children's education. At the same time, PdPR requires more attention and focus from parents to ensure their children attend classes consistently without any issues.

\section{ii) Poor Time Management}

Apart from that, some parents need to sacrifice their working hours at home. As an example, some housewives have no time for themselves as they are busy managing their children. Some parents have had to postpone their meetings. Not only that, parents who are also the frontliners such as nurses, doctors, police and many others are also affected. Poor time management among parents caused by their children's education may affect them physically and mentally. This situation causes stress and exhaustion among parents. In time, this issue will affect parents' working performance negatively which might cause them to be reprimanded by their employer or even fired.

\section{iii) Pressure from School Teachers}

Every day, parents are pressured by teachers to make sure their children attend online classes accordingly without considering the issues faced by the parents. As a result, parents may give up on monitoring their children and give freedom for the children to attend classes or not. We often see that in today's economy, parents, especially those that live in the rural areas, discourage their children from venturing into education and encourage them to work at a young age so they can help out their family financially.

\section{iv) Parents' Incompetency to Teach Children at Home}

Other than that, another issue that arises is that some parents worry about their competency to teach their children. This issue surfaces when the parents do not have enough knowledge of the subjects in their children's education. As we are all aware, not all parents have the basic criteria of a teacher. Therefore, it is understandable that some parents doubt their ability to teach their children at home. 
DEVELOPMENT

Vol. 10, No. 3, 2021, E-ISSN: 2226-6348 @ 2021 HRMARS

\section{v) DidikTV As an Alternative by the Ministry of Education}

Looking at the situation, parents are now able to breathe a sigh of relief as the Malaysian Ministry of Education (MOE) introduced an educational TV channel known as DidikTV KPM to overcome the issue that arose due to the PdPR. The Senior Minister of Education, Dr. Mohd. Radzi Md Jidin, said in Utusan Malaysia that the Ministry of Education has re-established conventional education TV to assist students with no access to the internet or lack of devices to attend online PdPR sessions. Therefore, a lot of parents said that they are grateful for DidikTV for being able to overcome the issues of online PdPR especially those who live in the rural area.

The Ministry of Education (MOE) is hoping that students can focus more on learning and increasing their understanding. With the existence of the educational TV, it is also hoped that all questions or missed lessons can be solved without having to depend on the help of parents. DidikTV KPM does not only benefit the children, but it is also able to increase parents' knowledge while they spend quality time watching the program together. To make sure that the program remains entertaining, parents can conduct the activities together with their children during the lesson. Parents can be alongside their children to assist and guide them. By doing so, parents can improve their bond with their children and witness the varying teaching methods utilised by teachers. Through this, parents will be able to gain further comprehension and understanding on teaching and conducting classes from the teachers.

\section{Conclusion}

Conclusively, the findings of this study report that one of the contributing factors to the psychological development of parents during the Movement Control Order (MCO) towards the overall process of Home-Based Teaching and Learning (PdPR) is the lack or difficulty of possessing a device to be used during PdPR. Electronic devices such as computers, laptops and tablets are necessary for PdPR. To add on, a stable internet connection also plays a crucial role in guaranteeing the PdPR session goes smoothly. These factors contribute to the emotional stress of parents especially those from the B40 community, who may also face issues such as unemployment and loss of income due to economic instability during MCO.

Emotional stress and other psychological problems impact parents who work-fromhome (WFH). Aside from carrying out working tasks and responsibilities at home, these parents also have to supervise their children's PdPR sessions. Furthermore, parents, commonly mothers are tasked with house chores including cooking and cleaning. These house chores further pile on their list of tasks and responsibilities during MCO. A decline in work performance can also be seen among WFH parents due to the overload of tasks to be completed at home. Additionally, teachers and educators assign several exercises for their students to complete during PdPR, which in turn burden the parents as they are responsible for supervising their children's at-home assignments. These factors could result in high levels of emotional stress among parents in Malaysia. The implications of this study highlight that parents' psychological issues can extend to their children as well. This has disastrous consequences such as neglect in their children's education. What is more, the mental health of parents could worsen, thus fearing that it could contribute to other negative issues such as suicide. To be able to control and improve their mental health, parents should instil moral values along with practising salah al-jama'ah (congregational prayer) with their family members. More recommendations include reciting the Quran and zikr to allow for the mind to always remember Allah SWT. Parents are also encouraged to participate in physical 
activities for the betterment of their physical and mental health. Instances of physical activities include playing badminton, gardening and cleaning the house.

The findings of this study could also contribute to the development of a parenting skill indicator and the management of Islamic psychology. These instruments can be used as a guide for the development of Islamic family welfare policies and future programs on family and parenting through relevant agencies. Relevant agencies include the Ministry of Women, Family and Community Development (KPWKM), the Ministry of Youth and Sports (KBS), the National Population and Family Development Board Malaysia (NPFDB), the Department of Social Welfare (JKM), the Department of Islamic Development Malaysia (JAKIM), and other related Non-Government Officials (NGOs).

\section{Contribution}

It is hoped that this study can help parents in identifying factors and causes that can contribute to psychological problems. In addition, it can also help find weaknesses in the PdPR implemented by the Ministry of Education. While we are aware that education is the most important thing in life, but we cannot ignore the development of mental health in fostering a harmonious society. When parents are ready to learn this PdPR, it will provide some relief and convenience to teachers and students to handle PdPR learning. The problems listed above should also be taken into account by the government in considering and re-evaluating the effectiveness of the implementation of PdPR.

Overall from this study, the researcher found that some gaps can still be studied in future studies. Especially the follow-up study using inferential statistical analysis through correlation and Mann-Whitney $U$ test. In addition, another study proposes to focus on parents who are among the educators themselves. This study is due to the existence of different environments for parents with different backgrounds as well as contributing to different opinions on opinions on the causes of the occurrence of parental psychological stress in the education of their children.

\section{Acknowledgement}

This project is funded under the Teja Grant (GDT2021/1-8), Universiti Teknologi MARA (UiTM), Melaka Branch. The highest appreciation to Universiti Teknologi MARA (UiTM), Melaka Branch for the assistance given to this project.

\section{Corresponding Author}

Hamidah Jalani

Academy of Contemporary Islamic Studies (ACIS), Universiti Teknologi MARA, Melaka Branch, Alor Gajah Campus, 78000 Alor Gajah Melaka, Malaysia.

Email: hamidahjalani@uitm.edu.my

\section{References}

Al-Ghazali \& Ahmad, A. H. M. (2000). Ihya' Ulum al-Din. (Al-Iraqi, Abdul Rahim bin al Husain Ed) al-Qaherah: Dar al-Taqwa li al Turath.

Al-Ghazali, Ahmad, A. H. M. (2010). Ihya' Ulum al-Din. Kaherah: Dar al-Taqwa li al Turath.

Ali, E., \& Rashid, M. A. (2020). Pandemik COVID-19: Mendepani Impak Psikososial. Terengganu Strategic \& Integrity Institute. 
Ashidah, N., \& Sham, F. M. (2020). Pendekatan Tazkiyat al-Nafs dalam Menangani Masalah Kemurungan. Jurnal al-Hikmah. 12(1).

Harian, B. (2020), PKP: Persekitaran kediaman sempit, sesak dedah kepada tekanan Mac 26, 2020. https://www.bharian.com.my/berita/nasional/2020/03/669564/pkppersekitaran-kediaman-sempit-sesak-dedah-kepada-tekanan

Brooks, S. K., Webster, R. K., Smith, L. E., Woodland, L., Wessely, S., Greenberg, N., \& Rubin, G. J. (2020). The psychological impact of quarantine and how to reduce it: rapid review of the evidence. The Lancet, 395(10227), 839-920. doi:https://doi.org/10.1016/S0140$6736(20) 30460-8$

Buang, S., \& Lee, A. (2020). Jangankan nak beli data, makan pun susah, keluh ibu. https://www.malaysiakini.com/news/520468

Chabraa, S. (2020). Psychological Implications of COVID-19 Pandemic. Journal of Evolution of Medical and Dental Sciences, 9(33), 2386-2391.

Chinazzi, M., Davis, J. T., Ajelli, M., Gioannini, C., Litvinova, M., Merler, S., . . Vespignani, A. (2020). The effect of travel restrictions on the spread of the 2019 novel coronavirus (COVID-19) outbreak. Science, 368(6489), 395-400. doi:10.1126/science.aba9757

Choi, E. P. H., Hui, B. P. H., \& Wan, E. Y. F. (2020). Depression and Anxiety in Hong Kong during COVID-19. International Journal of Environmental Research and Public Health, 17(10), 3740. MDPI AG. Retrieved from http://dx.doi.org/10.3390/ijerph17103740

Daud, M. A. M., \& Ramli, Z. (2020). Impak COVID-19 terhadap Pertumbuhan Penduduk Malaysia, Demografi dan Pembangunan Modal Insan. Universiti Kebangsaan Malaysia.

Families on the Edge. (2021), United Nations Childrens' Fund, Malaysia and the United Nations Population Fund (UNICEF). https://www.unicef.org/malaysia/reports/families-edgeissue-4

Greyling, T., Rossouw, S., \& Adhikari, T. (2020). A tale of three countries: How did Covid-19 lockdown impact happiness? GLO Discussion Paper, No. 584, Global Labor Organization (GLO), Essen. Retrieved from http://hdl.handle.net/10419/221748

Hamjah, S. H. (2020). Peranan kaunseling Islam Dalam Menghadapi Isu Kekeluargaan Semasa Pandemik Covid-19. Bicara Dakwah kali ke 21, Dakwah dalam Talian Semasa Pandemik. http://www/ukm/my/bicaradakwah/wp-content/uploads/2020/12/e-ProsidingBicara-Dakwah-Kali-Ke-21-71.pdf

Hayin, N. A. M. (2020). Mengurus Emosi, Mental ketika PKP, Metro, 3 Mei.

Irawan, A. W., Dwisona, L. (2020). Phsychological Impacts of Students on Online Learning During the Pandemic COVID-19. KONSELLI: Jurnal Bimbingan dan Konseling (EJournal).7(11),53-60.

Ismail, N., \& Hamjah, S. H. (2017). Pendekatan Tazkiyah al-Nafs Dalam Menghadapai Postpartum Depression: Satu Analisis Literatur. Jurnal Fikiran Masyarakat, Kemala Publisher

Jabatan Perdana Menteri. (2020). Siaran Media Kementerian Kewangan Malaysia-Bantuan Prihatin Nasional. Prime Minister's Office of Malaysia Official Website. April 25, 2021, www.pmo.gov.my.

Jarnawi J. (2020). Mengelola Cemas di Tengah Pandemik Corona. Jurnal Bimbingan dan Konseling Islam. 3(1).

Jiao, W. Y., Wang, L. N., Liu, J., Fang, S. F., Jiao, F. Y., Pettoello-Mantovani, M., \& Somekh, E. (2020). Behavioral and Emotional Disorders in Children during the COVID-19 Epidemic. The Journal of Pediatrics, 221, 266. https://doi.org/10.1016/J.JPEDS.2020.03.013 
Li, Z., Ge, J., Yang, M., Feng, J., Qiao, M., Jiang, R., Bi, J., Zhan, G., Xu, X., Wang, L., Zhou, Q., Zhou, C., Pan, Y., Liu, S., Zhang, H., Yang, J., Zhu, B., Hu, Y., Hashimoto, K., Jia, Y., ... Yang, C. (2020). Vicarious traumatization in the general public, members, and non-members of medical teams aiding in COVID-19 control. Brain, behavior, and immunity, 88, 916919. https://doi.org/10.1016/j.bbi.2020.03.007

Lim, W. J. (2020). Mengurus Emosi, Mental Ketika PKP. Harian Metro, 3 Mei.

Majid, M. A. (2020). Realiti dan Cabaran Dihadapi Pengurus Rumah Tangga Ketika PKP. https://www.tsis.my/wp-content/uploads/2020/06/PERSPEKTIF-Realiti-dan-CabaranDihadapi-Pengurus-Rumah-Tangga-Semasa-PKP-1.pdf.

Mapjabil, J., Kanyo, N., Hussin, R., Ab Rahman, B., Abentin, E., Datu Eranza, D. R., Abdul Rahim, A. H., \& Jetendra, M. H. (2020). Implications of the Movement Control Order Against Transmission Effect of Covid-19 Pandemic to the Wellbeing of Island Communities: A Review of Literature. Journal of Islamic, Social, Economics and Development (JISED), 5(32), $108-120$.

Megat, S. (2021). Bebanan murid, guru dan ibu bapa bertambah, NUTP mahu PdPR ditangguh. Retrieved from The Malaya Post: https://www.themalayapost.my/bebanan-muridguru-dan-ibu-bapa-bertambah-nutp-mahu-pdpr-ditangguh/

Mustaffa, N. (2020). Mengatasi Kebimbangan Semasa Pandemik Covid-19 dengan Pendekatan Teori Rational Emotive Behaviour Theraphy (REBT). Malaysian Journal of Sciences and Humanities (MJSSH). 5(11)

Noh, M. F. (2020). PKP: Persekitaran Kediaman Sempit, Sesak Dedah kepada Tekanan. Berita Harian, 26 Mac.

Orgilés, M., Morales, A., Delvecchio, E., Francisco, R., Mazzeschi, C., Pedro, M., \& Espada, J. P. (2020, June 26). Coping behaviors and psychological disturbances in youth affected by the COVID-19 health crisis. https://doi.org/10.31234/osf.io/2gnxb Philipson. J., Gorton, M., Turner., Shucksmith, M., Aitken-MCDermott, K., Areal F., Cowie,

Sahid, M. M., Hashimii, H., \& Amari, F. (2020). Prinsip Keluarga Islam Mendepani Norma Baharu Semasa Pandemik Covid-19. 3rd International Seminar on Islam and Science 2020 (SAIS2020) Universiti Sains Islam Malaysia.

https://www.researchgate.net/publication/344662280 Prinsip keluarga Islam Mendepani Norma baharu Semasa Pandemik.

Sutoyo, A. (2017). Bimbingan kaunseling Islam (teori dan Praktik). Yogyakarta: Pustaka Pelajar. Talha, R. (2020). Kajian Kes Impak Perintah Kawalan Pergerakan Kepada Penduduk Malaysia. https://www.dosm.gov.my/v1/uploads/files/6_Newsletter/Newsletter 2020/DOSM_BPPD_1-2020_Siri-17.pdf 